\title{
Rediscovery of the putatively extinct ant species Simopelta minima (Brandão) (Hymenoptera, Formicidae), with a discussion on rarity and conservation status of ant species
}

\author{
Carlos Roberto Ferreira Brandão ${ }^{1}$, Rodrigo Machado Feitosa ${ }^{1}$, Fernando Augusto Schmidt $^{2}$ \& \\ Ricardo Ribeiro de Castro Solar ${ }^{2}$
}

\begin{abstract}
${ }^{1}$ Museu de Zoologia da Universidade de São Paulo, Av. Nazaré 481, 04263-000 São Paulo-SP, Brazil. crfbrand@usp.br; rfeitosa@usp.br
${ }^{2}$ Laboratório de Ecologia de Comunidades, Departamento de Biologia Geral, Universidade Federal de Viçosa, Av. P. H. Rolfs s/n, 36570-000

Viçosa-MG, Brazil.schmidt.fa@gmail.com; rrsolar@gmail.com
\end{abstract}

\begin{abstract}
Rediscovery of the putatively extinct ant species Simopelta minima (Brandão) (Hymenoptera, Formicidae), with a discussion on rarity and conservation status of ant species. Simopelta minima (Brandão, 1989) was originally described based on four workers collected in soil samples from a small cocoa plantation in Ilhéus, state of Bahia, northeastern Brazil. In the subsequent years after the description, this cocoa plantation was eliminated and the species was then considered extinct by the Brazilian environmental institutions. The recent rediscovery of $S$. minima workers in subterranean pitfall trap samples from Viçosa, state of Minas Gerais, southeastern Brazil, over $1.000 \mathrm{~km}$ distant from type locality, suggests that the rarity and vulnerability status of some ant species may be explained by insufficient sampling of adequate microhabitats, in time and space.
\end{abstract}

KEYWORDS. Brazil; conservation; hypogaeic fauna; new record; rare ants.

RESUMO. Redescoberta da espécie supostamente extinta de formigas, Simopelta minima (Brandão) (Hymenoptera, Formicidae), com uma discussão sobre raridade e estado de conservação de espécies de formigas. Simopelta minima (Brandão, 1989) foi originalmente descrita com base em quatro operárias coletadas em amostras de solo provenientes de uma pequena plantação de cacau localizada em Ilhéus, Estado da Bahia, nordeste do Brasil. Nos anos seguintes à descrição, esta pequena plantação de cacau foi eliminada e a espécie passou a ser considerada extinta pelas instituições ambientais brasileiras. Recentemente foram coletadas operárias de Simopelta minima em amostras de armadilhas subterrâneas do tipo "pitfall", em Viçosa, Estado de Minas Gerais, sudeste do Brasil, a mais de 1.000 km de distância da localidade tipo. Esta redescoberta sugere que o status de raridade e/ou vulnerabilidade atribuído a algumas espécies de formigas pode ser explicado pela amostragem insuficiente de microhabitats adequados, no tempo e no espaço.

PALAVRAS-CHAVE. Brasil; conservação; fauna hipogéica; formigas raras.

Taxonomic account and collection data. Ants of the Neotropical ponerine genus Simopelta Mann (1922) share with Ecitoninae army-ants, by convergence, behavioral and morphological characteristics (Longino 2005). Workers forage in dense columns, generally raiding nests of other ants. When colonies are found with their own brood, this is generally of uniform size, suggesting synchronized immature development. Colony emigrations are encountered with workers transporting brood and the queen traveling with the column, suggesting nomadic behavior. In cases they are found inside cavities, it is unknown whether the Simopelta excavated the chambers themselves or occupied preexisting chambers, but the observations suggest periods of stable use of one nest site, similar to the stationary phase seen in Ecitoninae (Longino 2005). Workers also have small eyes, usually reduced to a single facet, and the queen is "dicthadiiform" (permanently wingless, with enlarged petiole and temporarily grossly swollen gaster) like those of Ecitoninae (Gotwald \& Brown
1996). Almost all known specimens of Simopelta were collected below the soil surface level, suggesting the preference of this genus for the hypogaeic habitat.

Simopelta is known from scattered localities throughout the Neotropics, in special from mid-montane wet forests (500 $2.000 \mathrm{~m}$ ). Several features of their biology result in their being infrequently collected. They are most abundant in a spatially restricted and less frequently visited habitat (mid-montane forests) and, despite often forming large colonies, they present a low density relative to other ants (Longino 2005).

Simopelta minima (Brandão 1989) was described based on only four workers extracted from $0-15 \mathrm{~cm}$ deep soil samples in Berlese funnels from a small, old shaded cocoa plantation ("cabruca") in Ilhéus, state of Bahia, northeastern Brazil. The specimens were collected by Dr. Jacques C. Delabie during 1986-1987. S. minima can be distinguished from other species of the genus by the combination of small size (total length less than $2.6 \mathrm{~mm}$ ), fine sculpture, presence of single-faceted eyes, 
lack of tibial peg-like setae, 4-segmented antennal club, and angulate, triangular, anteroventral petiolar process.

In the subsequent years after the description of S. minima, the fragment of cocoa plantation from where the species was uniquely known was gradually destroyed, until total elimination. As no other collection record of S. minima was so far made, in spite of the intense collecting effort in the region, Brazilian environmental institutions decided to consider the species as extinct (MMA 2007). In fact, as far as we know, $S$. minima was the first ant species considered extinct by human activity in the world. After that, this case has been amply divulged as an example of man-produced extinction in different popular and scientific publications.

On February 2nd, 2007, two of us (FAS and RRCS) collected 11 workers of $S$. minima in a semidecidual forest fragment of the Universidade Federal de Viçosa campus $\left(20^{\circ} 45^{\prime} 46.3^{\prime \prime S}\right.$, $42^{\circ} 51^{\prime} 45.1$ 'W), Viçosa, state of Minas Gerais, southeastern Brazil, over $1.000 \mathrm{~km}$ from $S$. minima type locality. This fragment was devastated by fire about nine years ago and presently is in the initial stage of regeneration, predominantly covered by herbaceous vegetation and sparse shrubs and trees (Martins et al. 2002).

The specimens were collected at $20 \mathrm{~cm}$ deep with subterranean pitfall traps. The traps consist of a plastic recipient (diameter $=8 \mathrm{~cm}$; height $=12 \mathrm{~cm}$ ) with an inner smaller recipient in its interior. The space between the two recipients was filled with a solution of water, detergent and salt. Two small plastic pots (empty tubes of photographic film, $3.3 \mathrm{~cm}$ diameter; 5.0 $\mathrm{cm}$ height) were placed in the inner recipient and partially filled with baits (sardine and honey, separately). Traps were then closed with plastic lids and buried. Four radial holes $(1 \mathrm{~cm}$ diameter) in the lateral of recipients allowed the hypogaeic ants to access the interior of the traps.

The workers recently collected in Minas Gerais increased the number of known $S$. minima specimens in museums from four to 15, deposited at the following institutions: Museu de Zoologia da Universidade de São Paulo, São Paulo, Brazil (six workers, including the holotype and one paratype); Laboratório de Ecologia de Comunidades, Universidade Federal de Viçosa, Minas Gerais, Brazil (six workers); Laboratório de Mirmecologia, Centro de Pesquisas do Cacau, Bahia, Brazil (one paratype worker, one Viçosa worker); Museum of Comparative Zoology, Harvard University, Cambridge, USA (one paratype worker).

One Viçosa worker, previously cleaned in acetone, was prepared for scanning electron microscope examination. The specimen was critical-point dried in a Balzer (Bal-Tec ${ }^{\circledR}$ CPD 030), and sputtered over with gold (Bal-Tec ${ }^{\circledR}$ SCD 050). After that, the specimen was mounted on the tip of a metallic triangle using silver glue and then fixated on a stub for the electron microscopy. Finally, the images were edited (Adobe PhotoShop ${ }^{\circledR}$ CS) to enhance brightness and contrast.

We compared the Viçosa specimens with the holotype and paratype workers deposited in the Museu de Zoologia, and were not able to find any significant difference. As in the original publication only drawings were provided, we present hereby SEM pictures of a Simopelta minima Viçosa worker, including frontal head view, detail of the clypeus and mandibles (showing the produced clypeal tooth) and the habitus in side and dorsal views. The only point we should comment is that in the original figures (Brandão 1989: Fig. 1) the head and frontal carinae shapes do not correspond exactly to the reality, although in the morphological account these characters are correctly described.

Incidentally, the first colleagues that tried to apply a name to this Simopelta sample, came across the name S. minima, but dismissed this possibility, because they found also the information the species was extinct.

Longino (2005) pictured and described a lone worker found in a mini Winkler sample taken in the forest between La Selva Biological Station's back boundary and Magsasay, at $150 \mathrm{~m}$ elevation. From his pictures, we believe this specimen belongs to a hitherto undescribed Simopelta species. This could also be the case of the specimens cited in the Colombian Biodiversity Inventory as Simopelta cf. minima (Sharkey 2006).

Rarity and conservation status of ant species: fact or artifact? Rarity, in its several meanings, has been dealt with by many authors (e. g. Rabinowitz et al. 1986; Kunin \& Gaston 1997; Murray \& Lepschi 2004). The main biological properties usually associated with rareness are: (1) small population size, (2) geographically restricted, localized populations, and (3) habitat specificity. Non-biological criteria are sometimes used, as the absence of collection for a long time, discovery outside the normal geographical range, or excessive difficult in finding a species by an expert in a single season (Rabinowitz 1981). These criteria, summed to the anthropic pressure on world's environments, are also employed to determine the species conservation status (Gärdenfors 2001; IUCN 2001). In this case, political and conservationist interests can converge in the rare and/or threatened species issue.

The rediscovery of the supposedly extinct Simopelta minima calls attention to the inaccuracy of various generalized criteria usually employed to determine rarity and conservation status in ant species. Very little or virtually nothing is known about the life-cycles, conditions of populations in the wild, or reproductive biology of several ant species considered rare. In addition, the lack of complete inventories in most biomes suggests that locally rare species can be fairly common because particular sites where their environmental niche requirements are best met favor high abundance. A further complication in considering taxa extinct or under severe threat without firm support may be the impairment of the development of adequate sampling techniques.

Obviously, there remains a set of rare species for which there is no current explanation for their true scarcity. A portion of the resident ant community may not be easily collected by any of the commonly used methods and techniques. For example, many myrmecologists have speculated that the subterranean ant fauna may be more abundant and diverse than generally thought (e. g. Belshaw \& Bolton 1994; Longino et al. 2002; Underwood \& Fisher 2006; Wilkie et al. 2007).

Biodiversity studies (Fowler \& Delabie 1995; Fowler et al. 

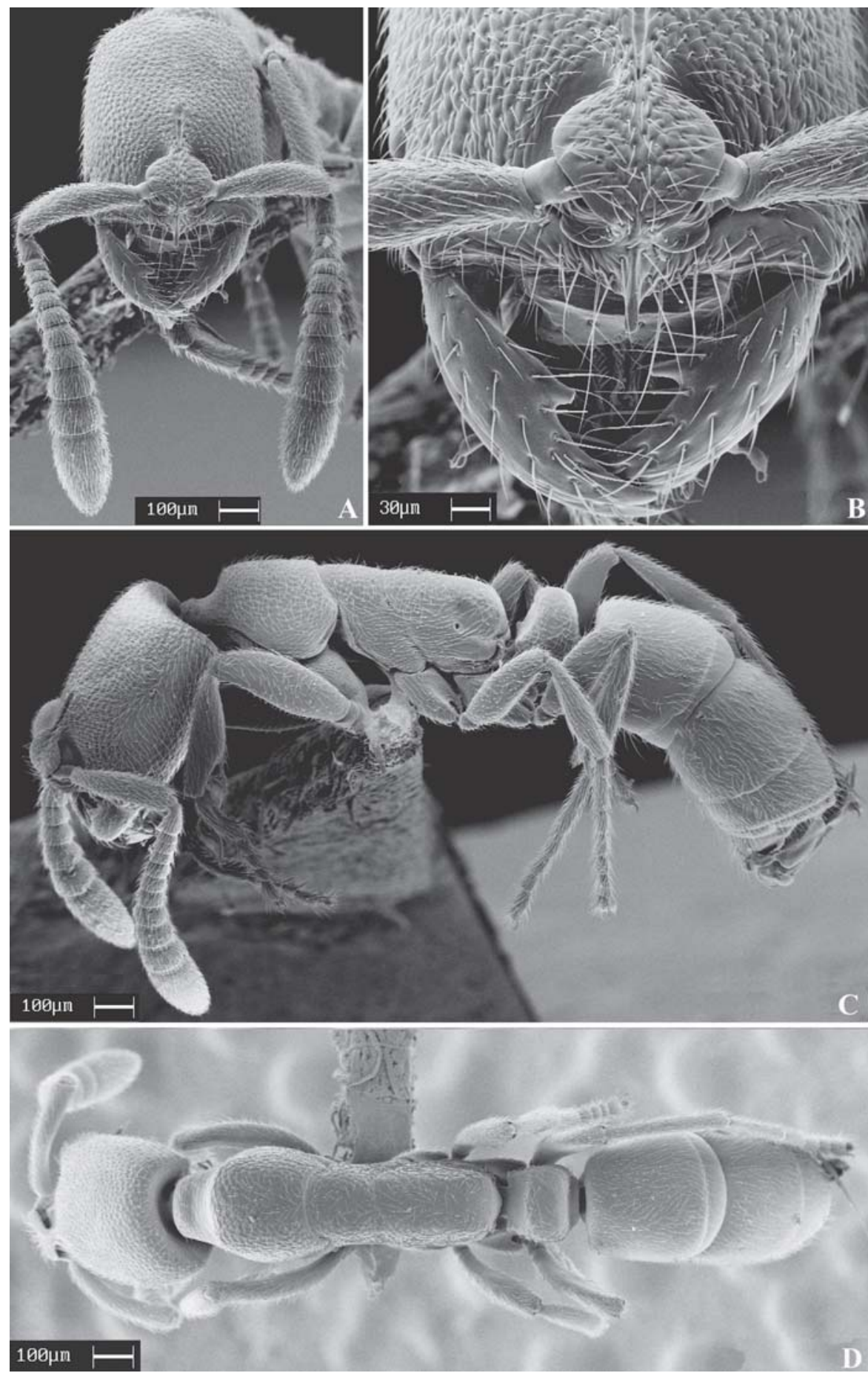

Fig. 1. Simopelta minima (Brandão), worker from Viçosa, Minas Gerais, Brazil. A, head in full-face view; B, detail of the clypeal area and mandibles (note the single facet eye at the left of the head lateral margin, near the superior border of the antennal scape); $\mathrm{C}$, Habitus in side view; (D) Habitus in dorsal view.

2000; Silva \& Silvestre 2004) have demonstrated a pronounced partitioning, as well as low similarity, on species composition between epigaeic and hypogaeic ants. In effect, even at hypogaeic habitats ant species composition can varies according to soil deepness (Wilkie et al. 2007) and other factors. Another example is the substantial increase in the collection records of rare ground-dwelling ants after the massive adoption of the Winkler apparatus in recent years (e.g. Agosti 1994; Brandão et al.1999).

Alternatively, rare species may have low densities at a given locality for a variety of reasons. They may be rare immigrants from a nearby source population or could result 
from temporal changes in populations, representing either the remnant of a declining population or the first individuals of an increasing population (Longino \& Colwell 1997).

We suggest that the supposed rarity of many ant species may be explained by their inconspicuity or by their scarcity, and by sampling difficulties in suitable microhabitats (for instance, social parasites and hypogaeic species) (Espadaler \& López-Soria 1991). In this way, many geographically restricted, rare, and/or threatened ant species might be widely distributed and even common if appropriate sampling techniques were employed in adequate temporal and spatial scales (DuBois \& Davis 1998; Longino et al. 2002; King \& Porter 2005).

Acknowledgements. The authors thank Carla R. Ribas for helping in the fieldwork and José Henrique Schoereder for the invaluable suggestions on a previous version of this manuscript. Lara M. Guimarães took the SEM images of Simopelta minima. We also thank CAPES, CNPq, FAPEMIG and FAPESP for financial support.

\section{REFERENCES}

Agosti, D. 1994. A revision of the South American species of the ant genus Probolomyrmex (Hymenoptera: Formicidae). Journal of the New York Entomological Society 102: 429-434.

Brandão, C. R. F. 1989. Belonopelta minima new species (Hymenoptera, Formicidae, Ponerinae) from eastern Brazil. Revista Brasileira de Entomologia 33: 135-138.

Brandão, C. R. F.; J. L. M. Diniz; D. Agosti \& J. H. C. Delabie. 1999. Revision of the Neotropical ant subfamily Leptanilloidinae. Systematic Entomology 24: 17-36.

Belshaw, R. \& B. Bolton. 1994. A survey of the leaf litter ant fauna in Ghana, West Africa (Hymenoptera: Formicidae). Journal of Hymenoptera Research 3: 5-16.

DuBois, M. B. \& L. R. Davis Jr. 1998. Stenamma foveolocephalum (=S. carolinense) rediscovered (Hymenoptera: Formicidae: Myrmicinae). Sociobiology 32: 125-135.

Espadaler, X. \& L. López-Soria. 1991. Rareness of certain Mediterranean ant species: fact or artifact? Insectes Sociaux 38: 365-377.

Fowler, H. G. \& J. H. C. Delabie. 1995. Resource partitioning among epigaeic and hypogaeic ants (Hymenoptera: Formicidae) of a Brazilian cocoa plantation. Ecología Austral 5: 117-124.

Fowler, H. G.; J. H. C. Delabie \& P. R. S. Moutinho. 2000. Hypogaeic and epigaeic ant (Hymenoptera: Formicidae) assemblages of Atlantic costal and dry mature and secondary Amazon forest in Brazil: continuums or communities. Tropical Ecology 41: 73-80.

Gärdenfors, U. 2001. Classifying threatened species at national versus global level. Trends in Ecology and Evolution 16: 511-516.

Gotwald, W. H. \& W. L. Brown Jr. 1966. The ant genus Simopelta
(Hymenoptera: Formicidae). Psyche 73: 261-276.

IUCN, 2001. The IUCN Red List of Threatened Species. Categories and Criteria (v. 3.1). Available in: http://www.iucnredlist.org/info/ categories_criteria2001. [accessed in August 17th, 2007].

King, J. R. \& S. D. Porter. 2005. Evaluation of sampling methods and species richness estimators for ants in upland ecosystems in Florida. Entomological Society of America 34: 1566-1578.

Kunin, E. \& K. J. Gaston. 1997. The Biology of Rarity. London, Chapman \& Hall, xiv +280 p.

Longino, J. T. 2005. Ants of Costa Rica Homepage. Overview of Simopelta. Available in: http://academic.evergreen.edu/projects/ ants/genera/SIMOPELTA/home.html. [Accessed in August 17th, 2007].

Longino, J. T.; J. Coddington \& R. K. Colwell. 2002. The ant fauna of a tropical rain forest: estimating species richness three different ways. Ecology 83: 689-702.

Longino, J. T. \& R. K. Colwell. 1997. Biodiversity assessment using structured inventory: capturing the ant fauna of a tropical rain forest. Ecological Applications 7: 1263-1277.

Mann, W. M. 1922. Ants from Honduras and Guatemala. Proceedings of the United States National Museum 61: 1-54.

MMA. 2007. Lista Nacional das Espécies da Fauna Brasileira Ameaçadas de Extinção. Ministério do Meio Ambiente. Available in: http:// www.mma.gov.br/port/ sbf/fauna/index.cfm. [Accessed in August 17th, 2007].

Martins, S. V.; G. A. Ribeiro; W. M. Silva Jr \& M. E. Nappo. 2002. Regeneração pós-fogo em um trecho de Floresta Estacional Semidecidual no município de Viçosa, MG. Ciência Florestal 12: $11-19$.

Murray, B. D. \& B. J. Lepschi. 2004. Are locally rare species abundant elsewhere in their geographical range? Austral Ecology 29: 287293.

Rabinowitz, D. 1981. Seven forms of rarity, p. 205-217. In: H. Synge (ed.). The Biological Aspects of Rare Plant Conservation. Chichester, John Wiley and Sons, xxviii+558 p.

Rabinowitz, D.; S. Cairns \& T. Dillon. 1986. Seven forms of rarity and their frequency in the flora of the British Isles, p. 182-204. In: M. E. Soulé (ed.). Conservation Biology: the Science of Scarcity and Diversity. Sunderland, Sinauer Associates, xiii+584 p.

Sharkey, M. 2006. Insect Survey of a Megadiverse Country: Colombia. Records of Simopelta cf. minima. Available in: http:// www.sharkeylab.org/biodiversity/db.php?app=colombia\&function= view_taxa\&genus $=$ Simopelta\&species $=$ minima. [Accessed in September 3rd, 2007].

Silva, R. R. \& R. Silvestre. 2004. Riqueza da fauna de formigas (Hymenoptera: Formicidae) que habita as camadas superficiais do solo em Seara, Santa Catarina. Papéis Avulsos de Zoologia 44: $1-11$.

Underwood, E. C. \& B. L. Fisher. 2006. The role of ants in conservation monitoring: If, when and how. Biological Conservation 132: 166-182.

Wilkie, K. T. R.; A. L. Mertl \& J. F. A. Traniello, 2007. Biodiversity below ground: probing the subterranean ant fauna of Amazonia. Naturwissenschaften 94: 392-395. 